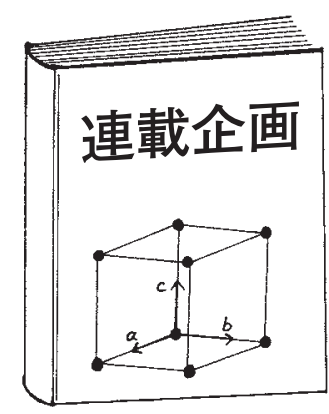

\title{
産業界で活躍する結晶学 (6)
}

\section{固体電解質探索と結晶構造解析}

\author{
高エネルギー加速器研究機構物質構造科学研究所 米村雅雄
}

\section{Masao YONEMURA: Crystal Structure Refinements Using Powder Diffraction Data for New Solid-State Electrolytes}

Crystalline-ionic conductors of lithium ions have been investigated since 1970s. They showed lower conductivity than silver and copper ones. Recently, new super lithium ionic conductor, LGPS system was designed and developed. This material showed quite high conductivity, $12 \mathrm{mS} / \mathrm{cm}$, but, its structure was completely new and unknown. By the assistance of crystallographic software using an ab initio method, the unknown structure was solved from multi-probe powder diffraction data. That type of software is really necessary on the material searching field.

\section{1. はじめに}

イオン導電体は, 固体の中をイオンが移動できる材料 を指す．代表的な材料には，教科書的な材料である $\alpha-\exists$ ウ化銀が有名である. $146^{\circ} \mathrm{C}$ 以上で相転移し，その高温 導電相のイオン導電率は, $1.3 \mathrm{~S} / \mathrm{cm}$ と液体中のイオンと 同程度以上に伝導する. ${ }^{1)}$ 可動イオンとして, 銀イオン だけでなく, 銅イオン,2),3) ナトリウムイオン,4)-6)リチウ ムイオン 7),8) や多価の陽イオン,9) さらに酸化物イオン, フッ素イオンといった陰イオン10) が導電する導電体な ど, 現在でも多くの材料が研究されている. 固体イオン 導電体の拈もしろさは, イオンが固体中をまるで液体の 中のように移動できることである。この現象は, 結晶性 材料だけでなく, 非晶質材料のガラス，ポリマーに扔い ても観測されている.しかし, この固体内で起こる高速 イオン移動現象がどのような微視的過程を経て起こる のかなど, 基礎科学的研究はまだ不十分であり, 電気化 学, 固体化学, 物理といった分野での理解を必要として いる. 一般に固体電解質は, イオン導電体として研究さ れており, 電池の電解質だけでなく, 各種センサーなど にも応用されている。

近年, 持続可能な社会を目指して, 化石燃料を極力使 わない環境にやさしい製品開発が活発である。その1つ としてハイブリッド自動車や電気自動車がある. 現在 の車載用蓄電池の性能では 1 回の充電で走れる航続距 離が短いのが問題となっている. そのため航続距離を長 くするエネルギー密度の高い蓄電池開発が熱望されて いる. 現在, その有望な電池システムとしてはリチウム イオン二次電池が1つの候補であり, 高出力, 高エネル ギー密度化を目指して研究されている. しかし, 高い性 能を求めると安全性が問題となる。記憶に新しいところ
として, 飛行機に搭載されたリチウムイオン二次電池の 発煙事故が発生した. ${ }^{11)}$ これは電池に流入する電流值が 異常になるなどの理由で電池内部が高温になり熱暴走と いう状態になったためと考えられている.市販のリチウ ムイオン二次電池では, 有機溶媒系の電解液が用いられ ており, 熱暴走すると内部の有機溶媒電解液が急激に高 温に加熱され燃焼してしまう危険性が指摘されている. そのため電池システムにはさまざまな安全装置を組み込 むことで安全を担保しているため, 事故になることは稀 であるが, 携带電話やパソコンに搭載されている電池か らの発煙・発火事故は少なからず発生している。より安 全性を高めるためにも, 不燃性の固体電解質の開発が急 務となっている。しかし，これまで多くの研究がなされ てきているがリチウムイオンの固体電解質のイオン導電 率は, 銀イオンや銅イオンに比べて非常に低い. 本記事 では, 固体電解質として主にリチウムイオン導電体を取 り扱い, 結晶性のリチウムイオン導電体の研究の歴史を 概観する. そして, 非常にパワフルな結晶学ソフトウェ アが, 最近発見されたイオン導電率が液体系電解質に匹 敵する新規超リチウムイオン導電体, $\mathrm{Li}_{4-x} \mathrm{Ge}^{4+}{ }_{1-x} \mathrm{P}^{5+}{ }_{x} \mathrm{~S}_{4}$ の一般式で表せるLGPS系という物質群の未知構造解析 およびイオンの導電経路を推測するのに役立った研究例 を紹介する。

\section{2. リチウムイオン導電体（固体電解質）}

イオン導電体においては, これまでガラスと結晶のイ オン導電体が多数研究されてきた。しかし, それらガラ スと結晶性のイオン導電体では材料設計がまったく異 なる.ガラス系では, その構造を乱れさせることでイオ ン導電性を向上させる. その一方で, 結晶性材料ではイ オン導電により適した構造を構築することでイオン導 
表1結晶性リチウムイオン導電体の導電率.（Conductivity of glassy lithium ionic conductors.)

\begin{tabular}{lcll}
\hline Compound & $\begin{array}{c}\text { Conductivity at r.t. } \\
\left(\sigma / \mathrm{Scm}^{-1}\right)\end{array}$ & Reference & \\
\hline $\mathrm{LiI}$ & $5.5 \times 10^{-7}$ & Schlaikjer et al. $(1973)$ & $14)$ \\
\hline $\mathrm{Li} \mathrm{N} \mathrm{N}$ & $1.0 \times 10^{-3}$ & Lapp et al. $(1983)$ & $15)$ \\
\hline $\mathrm{Li}-\beta$-alumina & $1.3 \times 10^{-4}$ & Whittingham et al. $(1972)$ & $16)$ \\
\hline $\mathrm{Li}_{2} \mathrm{CdCl}_{4}$ & $1.1 \times 10^{-6}$ & Kanno et al. $(1988)$ & $17)$ \\
\hline $\mathrm{La}_{0.5} \mathrm{Li}_{0.5} \mathrm{TiO}_{3}$ & $1.0 \times 10^{-3}$ & Inaguma et al. $(1994)$ & $18)$ \\
\hline $\left.\mathrm{LISICON} \mathrm{Li}_{14} \mathrm{Zn}\left(\mathrm{GeO}_{4}\right)_{4}\right)$ & $6.0 \times 10^{-7}$ & Hong et al. $(1978)$ & $19)$ \\
\hline $0.6 \mathrm{Li}_{4} \mathrm{GeO}_{4}-0.4 \mathrm{Li}_{3} \mathrm{VO}_{4}$ & $3.0 \times 10^{-5}$ & West et al. $(1980)$ & $20)$ \\
\hline $0.5 \mathrm{Li}_{3} \mathrm{PO}_{4}-0.5 \mathrm{Li}_{4} \mathrm{SiO}_{4}$ & $4.0 \times 10^{-6}$ & Hu et al. $(1977)$ & $21)$ \\
\hline $0.4 \mathrm{Li}_{4} \mathrm{SiO}_{4}-0.6 \mathrm{Li}_{3} \mathrm{VO}_{4}$ & $1.7 \times 10^{-5}$ & Kuwano et al. $(1981)$ & $22)$ \\
\hline $\mathrm{Li}_{3} \mathrm{PS}_{4}$ & $3.0 \times 10^{-7}$ & Tachez et al. $(1984)$ & $23)$ \\
\hline $\mathrm{Li}_{2} \mathrm{SiS}_{3}$ & $2.0 \times 10^{-6}$ & Huggins et al. $(1989)$ & $24)$ \\
\hline $\mathrm{Li}_{4} \mathrm{SiS}_{4}$ & $5.0 \times 10^{-8}$ & Huggins et al. $(1989)$ & $24)$ \\
\hline
\end{tabular}

電性を向上させる設計指針を用いる. 銀イオン導電体で は, ガラス系材料 $\left.\left(\mathrm{AgI}-\mathrm{Ag}_{2} \mathrm{MoO}_{4}\right)^{12}\right)$ および結晶性材料 $\left.\left(\mathrm{RbAg}_{4} \mathrm{I}_{5}\right){ }^{13}\right)$ において, ほぼ同等のイオン導電性 $\left(10^{-1}\right.$ 〜 10 $-2 \mathrm{~S} / \mathrm{cm})$ を示す材料が発見されているが, 一般的に ガラス系材料が先行して研究がされ, 結晶性材料のイオ ン導電率が追いつき, 追い抜く傾向がある, 結晶性材料 は, 物質設計に従って材料合成を行っても, 期待される 組成と構造になることは少なく, 高導電性を示す結晶構 造を構築するのが非常に難しいからである。しかし, 銀 イオンや銅イオンでは, ガラス系に比べ, 結晶性のイオ ン導電体のほうが最終的には高イオン導電性材料が発 見されている。リウムムイン導電体もその傾向があっ た. 本記事では結晶性材料のリチウムイオン導電体に 絞って, これまでのリチウムイオン導電体を紹介する。 まず, 代表的な例を表 1 に示し, 各リチウムイオン導電 体について短くまとめることにする.

\section{1 ヨウ化リチウム, Lil}

リチウム導電体の探索は1970年代頃から始まり, LiX $(\mathrm{X}=\mathrm{F}, \mathrm{Cl}, \mathrm{Br}, \mathrm{I})$ のハロゲン化リチウムが最初と言え る. LiIの結晶構造は, ほかのハロゲン化リチウムと同 様の $\mathrm{NaCl}$ 型の構造であるが, I-イオンの分極が大きいた め, $10^{-7} \mathrm{~S} / \mathrm{cm}$ というイオン導電性が発現する。これは液 体に比べれば非常に低いイオン導電率であったが, 1972 年にペースメーカ用電池の電解質として実用化されてい る. 電池内で, 正極 (ヨウ素錯体) と負極材料 (金属リチ ウム) を接触させた界面において自動的に薄膜の固体電 解質相が生成し, 固体電池を形成する. 自然に固体電解 質が界面上に生成するため, 内部短絡しにくく固体電池 として高い信頼性があった。

\section{2 窒化リチウム, $\mathrm{Li}_{3} \mathrm{~N}$}

この材料は, 図 $1 \mathrm{a} に$ 示すように, $\mathrm{Li}_{2} \mathrm{~N}$ 層と $\mathrm{Li}$ 層が交 互に積層する六方晶系層状構造である. ${ }^{25)}$ Lapp らが単結 晶による導電率測定を行い, $c$ 軸方向 $\left(10^{-5} \mathrm{~S} / \mathrm{cm}\right)$ に対 して, $a b$ 平面のイオン導電率 $\left(1.2 \times 10^{-3} \mathrm{~S} / \mathrm{cm}\right)$ が 2 桁高 く, $\mathrm{Li}$ 層の $\mathrm{Li}$ が $a b$ 平面の二次元拡散が主に導電に寄与 (a)

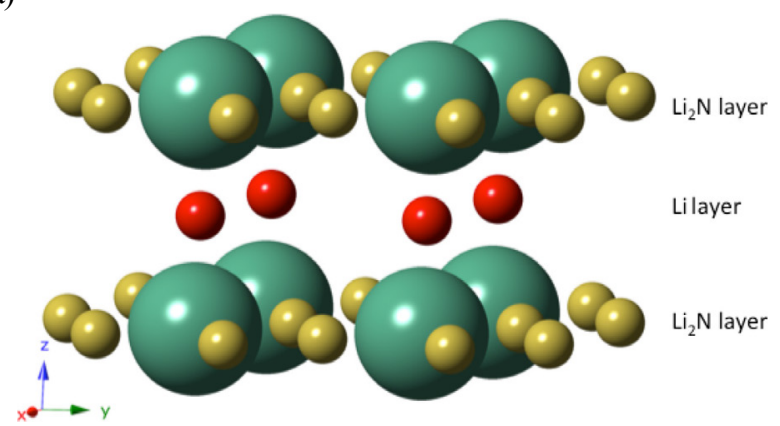

(b)

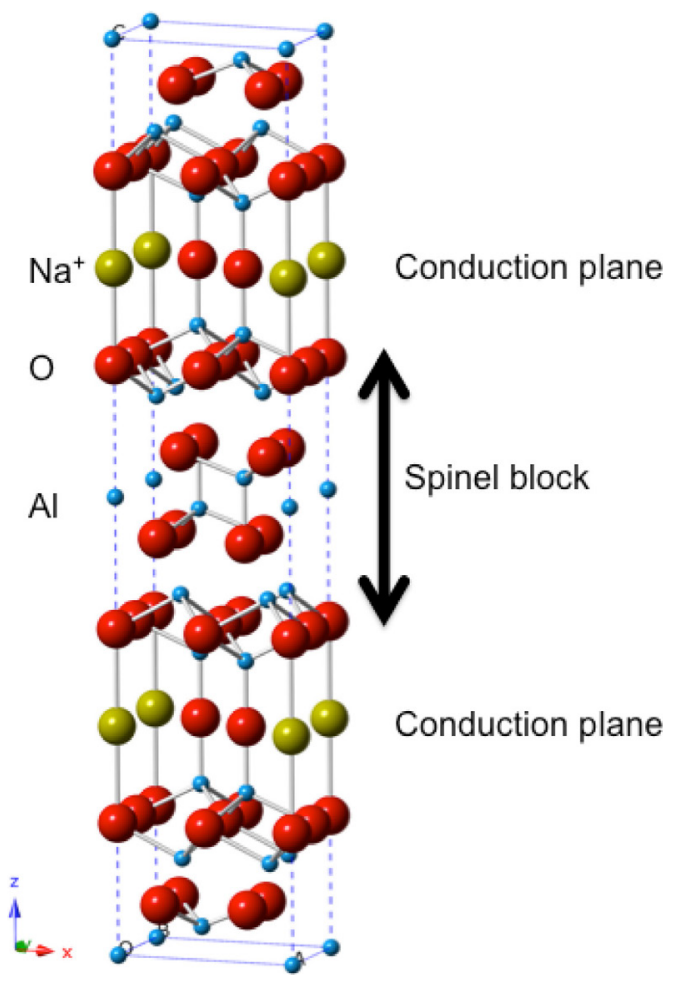

図 $1 \mathrm{Li}_{3} \mathrm{~N}(\mathrm{a})$ と Li- $\beta$-アルミナ (b) の結晶構造. (Crystal structures of $\mathrm{Li}_{3} \mathrm{~N}$ (a) and Li- $\beta$-alumina (b).)

していることを明らかにした.26) しかし，この系の導電 率は, 合成条件などで大きく変化する矛盾した報告が多 
く, 不純物の混入や組成の変化により, 特性が大きく変 化すると考えられる。この材料の実用化が難しかったの は， $0.45 \mathrm{~V}$ という低い分解電圧にあった，そのためさま ざまな窒化物誘導体が合成され，分解電圧を上げる試み がなされた. $\mathrm{Li}_{3} \mathrm{~N}-\mathrm{LiI}-\mathrm{LiOH}$ の成分系において 1.6 $1.8 \mathrm{~V}$ の分解電圧が見出された. ${ }^{27)}$ さらに $\mathrm{Li}_{3} \mathrm{~N}$ に遷移金属 の $\mathrm{Co}, \mathrm{Ni}, \mathrm{Cu}$ といった遷移金属イオンをドープして得 られる分解電圧が $1 \mathrm{~V}$ 以上の材料も研究された. ${ }^{28}$

\subsection{Li- $\beta$-アルミナ}

$\beta-ア ル ミ ナ は ~ N a / S$ 電池で実用的に使われており, 典型 的な二次元拡散のイオン導電体である. Li- $\beta$-アルミナ ${ }^{16)}$ は, Na- $\beta$ アルミナとのイオン交換により得られる。 その 構造は図1bに示したように, $\mathrm{O}^{2-}$ の立方最密配置による 八面体と四面体の間隙に $\mathrm{Al}^{3+}$ が入るスピネルブロック構 造である. スピネルブロックは交互に積層することで, Liイオンを含む導電レイヤーが構築される構造となっ ている.

\section{$2.4 \mathrm{Li}_{2} \mathrm{MCl}_{4}$}

$\mathrm{AB}_{2} \mathrm{X}_{4}$ で表現されるスピネル構造は, $\mathrm{A}$ イオンと $\mathrm{B} イ$ オンが四面体位置と八面体位置に存在する $\mathrm{X}$ イオンの立 方最密充填構造であることは説明の必要はないだろう。 この材料系は, 四面体位置と八面体位置の半分をリチウ ムイオンが占める逆スピネル型である. 四面体位置のリ チウムは, スピネルの骨格構造の作る三次元に広がる トンネル構造に位置する。 そのため, $\mathrm{Li}_{2} M \mathrm{Cl}_{4}(M=\mathrm{Cd}$, $\mathrm{Mg}, \mathrm{Mn}, \mathrm{V})$ のハロゲン化物は, 比較的低温で高いリチ ウムイオン導電性を示すことが報告されている. ${ }^{17)}$

\section{$2.5 \mathrm{La}_{0.5} \mathrm{Li}_{0.5} \mathrm{TiO}_{3}$}

$\mathrm{ABO}_{3}$ の一般式で表されるペロブスカイトは三次元構 造を有して抢り， $\mathrm{BO}_{6}$ 八面体が頂点共有し，12配位の $\mathrm{A}$ サイトによる骨格構造を有している。リチウムイオン含 有ペロブスカイト $\left(\mathrm{La}_{2 / 3}-x \mathrm{Li}_{3 x} \mathrm{TiO}_{3}\right)$ 系 ${ }^{18)}$ は, 高リチウム イオン導電体として広範囲に研究されてきた。この系で

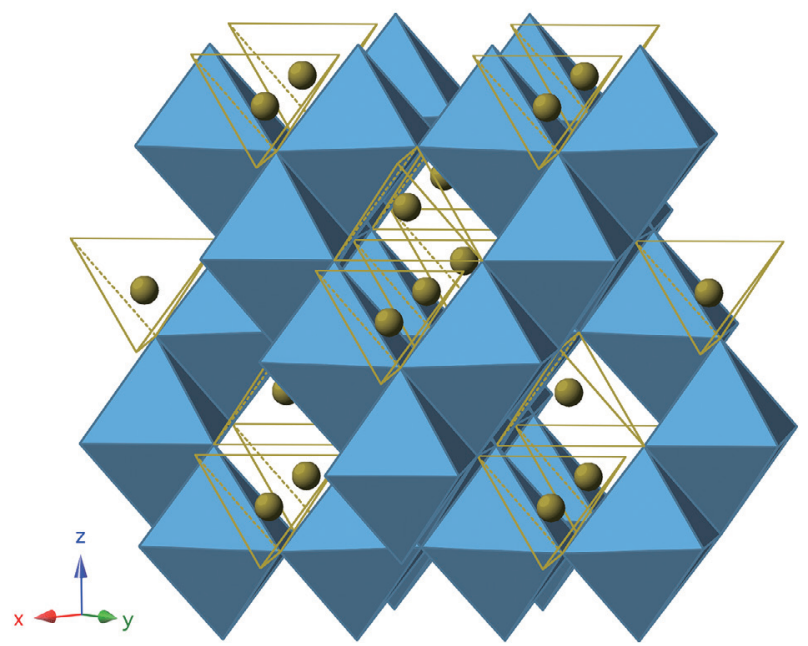

図2 $\mathrm{Li}_{2} \mathrm{MCl}_{4}$ の結晶構造. (Crystal structures of $\mathrm{Li}_{2} M \mathrm{Cl}_{4}$.)
は, Li イオンはより大きい $\mathrm{La}^{3+}$ イオンとともにAサイト を占有する，Liイオンは，Aサイトの中心を占有するの ではなくて, Aサイトが2つの歪んだ四面体位置の1つ に偏っている. その結果, リチウムイオンの偏りによっ て生じる $\mathrm{A}$ サイト位置周辺の多くの欠陥が構造中に現 れる、そのため, リチウムイオンが欠陥を介して移動で き, 高い導電率 $\left(10^{-5} \sim 10^{-3} \mathrm{~S} / \mathrm{cm}\right)$ を示すことになる.

\subsection{LISICON}

リチウムイオン導電体において, LISICON (LIthium Super Ionic CONductor) ${ }^{19)}$ と呼ばれる酸化物の物質群が ある. $\mathrm{Li}_{4} \mathrm{GeO}_{4}$ を母構造とした材料に, $\mathrm{Zn}$ が固溶した $x \mathrm{Li}_{4} \mathrm{GeO}_{4}-(1-x) \mathrm{Zn}_{2} \mathrm{GeO}_{4}$ で表されるイオン導電体に付け られた総称である. 現在は $\gamma-\mathrm{Li}_{3} \mathrm{PO}_{4}$ (高温相) 型の $\mathrm{LiO}_{4}$, $\mathrm{GeO}_{4}, \mathrm{SiO}_{4}, \mathrm{PO}_{4}, \mathrm{ZnO}_{4}, \mathrm{VO}_{4}$ という四面体と $\mathrm{LiO}_{6}$ 八面 体により形成される骨格構造をもつ酸化物物質群全体 の名称として使われている。この物質群には広い固溶領 域がある，異なる価数のイオンと置換することで $\mathrm{Li}$ 欠 損や過剩 $\mathrm{Li}$ の導入が容易であり, 構造と組成をさまざ まに変化させることができるのが特徴である，例えば, $\mathrm{Li}_{4} \mathrm{GeO}_{4}$ を母構造にして, $\mathrm{Li}$ 欠損を導入にするには $\mathrm{Al}^{3+}$ を部分置換させ, $\mathrm{Li}_{4}-3 x \mathrm{Al}_{x} \mathrm{GeO}_{4}$ 固溶体を合成でき，格子 間 $\mathrm{Li}$ を導入するには, $\mathrm{P}^{5+}$ を $\mathrm{Ge}^{4+}$ と部分置換することで $\mathrm{Li}_{3+x} \mathrm{P}_{1-x} \mathrm{Ge}_{x} \mathrm{O}_{4}$ 固溶体を合成できる。

\subsection{Thio-LISICON}

2.6で示したLISICONは，酸化物系材料である。イ オン導電率をより向上させるために, 酸素の代わりに より分極率の高い硫黄を用いることが次に検討され た。菅野と入江らは, $\mathrm{Li}_{2} \mathrm{~S}-\mathrm{GeS}_{2}, \mathrm{Li}_{2} \mathrm{~S}-\mathrm{GeS}_{2}-\mathrm{ZnS}, \mathrm{Li}_{2} \mathrm{~S}-$ $\mathrm{GeS}_{2}-\mathrm{Ga}_{2} \mathrm{~S}_{3}$ といった硫化ゲルマニウム系を基本とする 物質群を探索した。このときに, $\mathrm{Li}_{2} \mathrm{~S}-\mathrm{GeS}_{2}-\mathrm{Ga}_{2} \mathrm{~S}_{3}$ で高

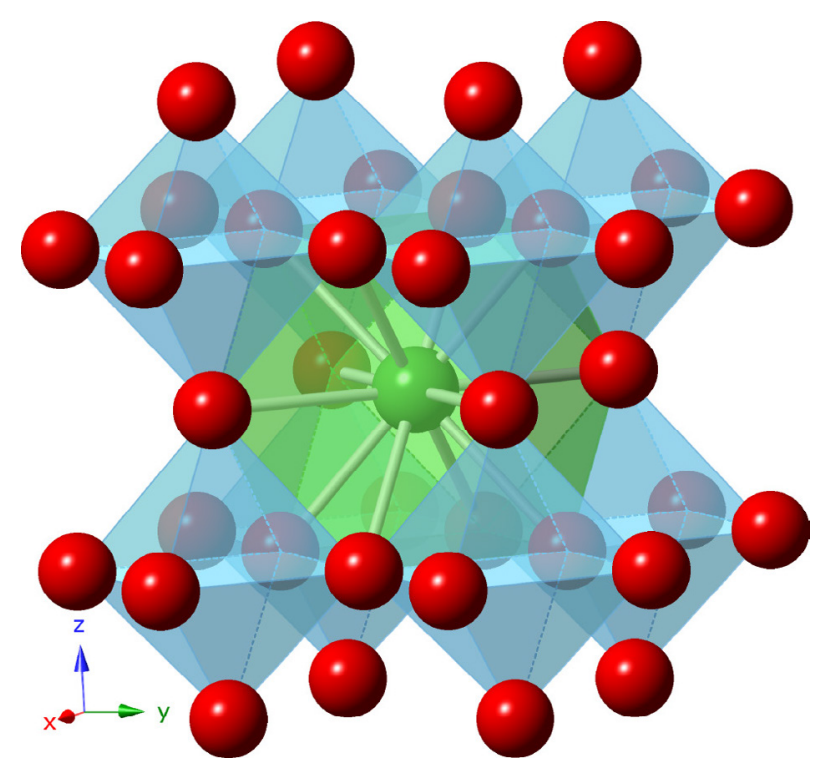

図3 $\mathrm{La}_{0.5} \mathrm{Li}_{0.5} \mathrm{TiO}_{3}$ の結晶構造. (Crystal structures of $\mathrm{La}_{0.5} \mathrm{Li}_{0.5} \mathrm{TiO}_{3}$.) 


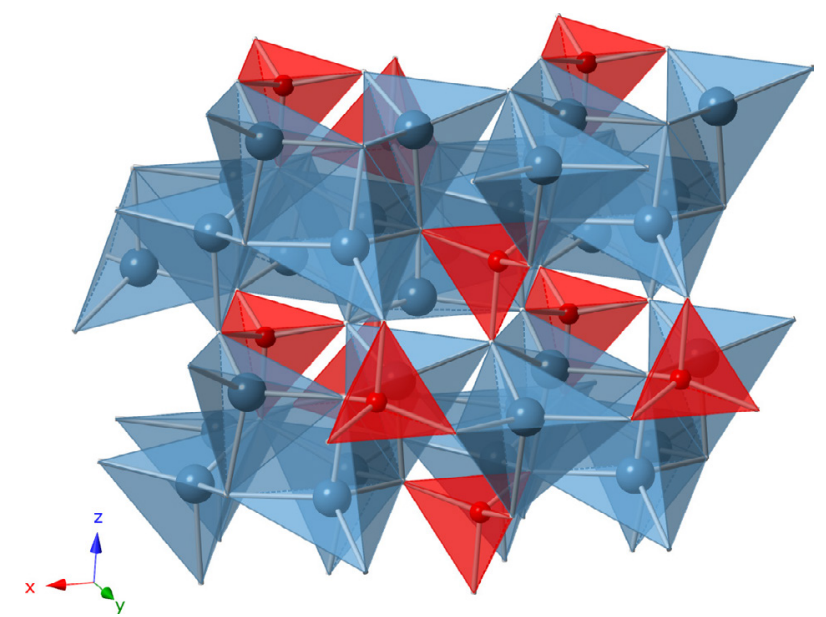

図4 $\gamma-\mathrm{Li}_{3} \mathrm{PO}_{4}$ の結晶構造. (Crystal structures of $\gamma-\mathrm{Li}_{3} \mathrm{PO}_{4}$.)

い導電率を示す物質を発見したが，そのX線回折図形 は, LISICONに酷似していることに気づき, 酸化物の LISICON とこの硫化物の物質系の構造が同じであるこ とを発見した，それで，菅野らはこの物質系を酸化物 のLISICONに対して，硫化物を示すThioを付け加え てThio-LISICONと命名した，その後の研究に扔いて， $\mathrm{Li}_{x} M_{1-y} M^{\prime} y \mathrm{~S}_{4}\left(M=\mathrm{Si}, \mathrm{Ge}, M^{\prime}=\mathrm{P}, \mathrm{Al}, \mathrm{Zn}, \mathrm{Ga}, \mathrm{Sb}, \mathrm{V}\right)$ が探索された結果, これらの物質が $\gamma-\mathrm{Li}_{3} \mathrm{PO}_{4}$ 型の骨格 構造を有し, 室温で $10^{-7} \sim 10^{-3} \mathrm{~S} / \mathrm{cm}$ の導電率を示すこ とを明らかにした. ${ }^{18)}$ さらに村山らは, $\mathrm{Li}_{4-x} \mathrm{Ge}_{1-x} \mathrm{P}_{x} \mathrm{~S}_{4}$ の 固溶体で, $2.2 \times 10^{-3} \mathrm{~S} / \mathrm{cm}$ という材料を発見した. ${ }^{29)} こ$ の $\mathrm{Li}_{4-x} \mathrm{Ge}_{1-x} \mathrm{P}_{x} \mathrm{~S}_{4}$ の固溶体が, 現在, 世界最高のリチウ ムイオン導電体, LGPS系の発見へとつながった材料で ある. ${ }^{30)}$

\section{3. 新規リチウムイオン導電体の設計指針}

このように固体電解質としてのイオン導電体は, 広く 研究されており, その物性と構造には学術的にも産業的 にも非常に興味がもたれている。一般的には, 結晶を構 成する各イオン・原子は格子点上に固定され，それが結 晶内を移動することは困難である。しかし，イオン導電 体においてはイオンが作る副格子の中を融点よりも低 い温度で，イオンが拡散することができる，そのような 高速なイオン導電を実現させる材料設計指針としては, 次の 2 点が考えられる.

（1）さまざまな陽イオン，陰イオンを用いて部分置換す ることで, 高イオン導電相の構造をより低温におい て安定化させる。

（2）イオン導電に適した骨格構造を有した材料系を選択 する。

ということが考えられる.

上記の（1）の指針によって, 銅イオンや銀イオンの導 電体が発見されることになり, $\alpha-\mathrm{AgI}$ の高温相の構造を より低温に抢いても安定化させ, 低温から高いイオン導
電性を示す $\mathrm{Rb}_{4} \mathrm{Cu}_{16} \mathrm{I}_{7} \mathrm{Cl}_{13}$ や $\mathrm{RbAg}_{4} \mathrm{I}_{5}$ の発見へとつながっ た. 一方，(2)の設計指針によって, リチウムイオンやナ トリウムイオンの高イオン導電体が発見されている. 例 えば, 2.3 で示したスピネル型リチウム遷移金属塩化物 や，2.5のLISICON，さらにそのナトリウム版NASICON (Na Super Ionic CONductor) ${ }^{31}$ ) といった材料は, 基本と なる骨格構造を決定した後, 一般的な固体化学の手法 を用いることで, イオン導電率を急速に向上させている. その固体化学的手法とは，下記の $(\mathrm{a}) \sim(\mathrm{c})$ である.

(a) 格子内に, 異なる価数のイオンを導入し, 欠陥もし くは格子間イオンを導入すること

(b) イオン半径の異なるイオンと置換することでイオン 拡散経路上のボトルネックを最適化すること

(c) 高い分極率をもつイオン拡散種もしくは陰イオンに よる副格子を作ること

ここで固溶体の形成について, 少し考えてみたい. 固 溶体を作る理由は, その端成分となる材料の特性や構造 を変えるためである. 形式電荷が同じイオンで置換する と, 結晶学的に等価な位置に異なるイオンが部分的に入 れ替わることにより，イオン半径の違いからわずかに歪 みを導入することができる. また異なる価数のイオンで 置換すると, その結晶学的に等価な位置が置換するとし た場合, 電荷補償のため, 欠陥や格子間のイオンが導入 されることになり, 電子やホールが導入され材料の特性 を大きく変化させることができる。

これまで (a) と（b) の材料設計指針による広範囲の物 質探索により, 多くの材料が発見されている. LISICON 系はそのよい例である。これらの材料は, 同じ骨格構造 を有しながらも広い固溶領域を示し, 結晶学的には等価 な位置に異なる価数のイオンで置換することができる. その結果として, 格子間リチウムやリチウム欠損を導入 することができ, イオン導電性を向上させることができ た．しかしながら酸化物 LISICON系では, イオン導電率 が $10^{-6} \mathrm{~S} / \mathrm{cm}$ 程度と低い導電性で, 銅イオンや銀イオンに 比べてかなり低い導電性の材料しか発見されていない. その後, 導電性を向上させるために, 酸素をより分極率 の大きい硫黄に置換したThio-LISICON系材料の探索が なされるようになった. Thio-LISICON系材料は, 先述し たように, 酸化物 LISICON と同じ結晶構造であり, 広い 固溶領域をもつ物質系である。この系に対しても, 異な る価数のイオンを置換する手法を適用した結果, LGPS 系と呼ばれる世界最高の導電率をもつ物質系が発見さ れることとなった。

\section{4. 新規リチウムイオン導電体LGPS系の発見}

2000 年代に入り Thio-LISICON系の発見により, イオ ン導電率が室温で $10^{-3} \mathrm{~S} / \mathrm{cm}$ にまで向上した。これは有 機溶媒系の電解液の導電率, $10^{-2} \mathrm{~S} / \mathrm{cm}$ にまで, あと 1 桁 
に迫る大きな前進であった。この Thio-LISICON系の材 料は, 1970 年代に発見されていた $\mathrm{Li}_{3} \mathrm{~N}$ と同程度の導電 率であるが, 分解電圧が $5 \mathrm{~V}$ 程度と高く, 十分にリチウ ムイオン二次電池の固体電解質として利用可能である ところが, $\mathrm{Li}_{3} \mathrm{~N}$ とはまったく異なり，画期的な材料系で あった。

LGPS系材料発見のきっかけは菅野らが盛んに物 質探索していたこのThio-LISICON系材料に始まる. Thio-LISICON系材料は $\gamma-\mathrm{Li}_{3} \mathrm{PO}_{4}$ 型の骨格構造を有した $\mathrm{Li}_{4} \mathrm{GeS}_{4}-\mathrm{Li}_{3} \mathrm{PS}_{4}$ の固溶体の $\mathrm{Li}_{3.25} \mathrm{Ge}_{0.25} \mathrm{P}_{0.75} \mathrm{~S}_{4}$ で, 最も高い 導電率 $\left(2.2 \times 10^{-3} \mathrm{~S} / \mathrm{cm}\right)$ が得られた。 この固溶体から複 雑な構造に起因する超格子反射を含む回折図形が得ら れた，菅野らは，そのような構造で, なぜイオン導電率 が急激に向上するのかに注目し，この領域の材料を丁寧 にさらに探索した，その結果，最終的に $1.2 \times 10^{-2} \mathrm{~S} / \mathrm{cm}$ のLGPS系という結晶構造が異なる新規相を発見するこ ととなった 30 )

\section{LGPS系の未知結晶構造解析}

LGPS 系固体電解質は, Thio-LISICON系の $\mathrm{Li}_{4} \mathrm{GeS}_{4}$ と $\mathrm{Li}_{3} \mathrm{PS}_{4}$ の固溶体の領域に存在する 1 つの相である。この 固溶相, $\mathrm{Li}_{4-x} \mathrm{Ge}_{1-x} \mathrm{P}_{x} \mathrm{~S}_{4}$ の合成条件を最適化することで現 在 $0.5<x<0.67$ でのみ, 新規の高リチウムイオン導電 であるLGPS系を出現させることができる、30)このきわ めて高いイオン導電性が, どのような結晶構造から発現 し, どのようなイオン導電機構によってイオンが拡散し ているのかは, さらに高性能な材料設計のための大変重 要な情報となる。

LGPS 系固体電解質の組成は, 高周波誘導結合プラズ マ発光分光分析法 (ICP) 測定による化学組成分析で, $\mathrm{Li} ： \mathrm{Ge} ： \mathrm{P} ： \mathrm{~S}=10 ： 1 ： 2 ： 12$ と解析された. 次に結晶 構造を明らかにするために，X線回折測定を行った，図5 にこの固溶体の端成分の $\mathrm{Li}_{4} \mathrm{GeS}_{4}$ と $\mathrm{Li}_{3} \mathrm{PS}_{4}$ のシミュレー

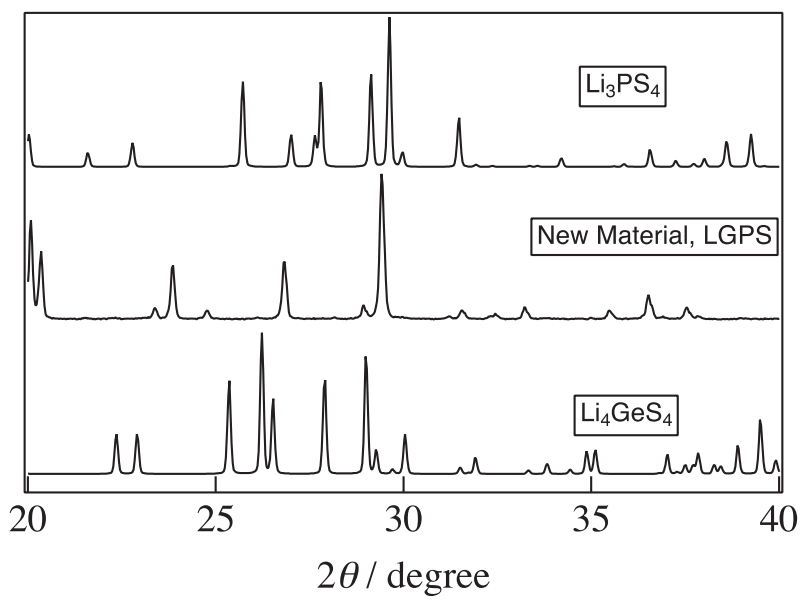

図5 $\mathrm{Li}_{4-x} \mathrm{Ge}_{1-x} \mathrm{P} x \mathrm{~S}_{4}$ 系のX線回折測定図形. . X-ray diffraction patterns for $\mathrm{Li}_{4-x} \mathrm{Ge}_{1-x} \mathrm{P}_{x} \mathrm{~S}_{4}$ system.)
ション回折図形と, LGPS系イオン導電体の回折図形を 示す. LGPS系イオン導電体は端成分のどちらの結晶構 造とも異なることが明らかとなった。つまり,このLGPS 系イオン導電体は, $\mathrm{Li}_{4} \mathrm{GeS}_{4}$ と $\mathrm{Li}_{3} \mathrm{PS}_{4}$ の固溶体であるが, どちらの構造も LGPS系固体電解質の母構造ではなかっ た、種々の構造データベースとも照合したが, 類似の回 折図形は存在して抢らず, まったく未知の結晶構造で あった。この材料の発見当初, LGPS系イオン導電体は 単結晶ではなく粉末多結晶でしか得られていなかった ため, 未知構造を解くために粉末回折デー夕を用いるし かなかった，そのため, この結晶構造を解くために，(1) 指数付けプログラムにより単位格子の格子定数と晶系を 明確にし，(2) 粉末回折図形による $a b$ initio 法による構 造モデルの大域最適化を行う手法を初めて試すことにし た.この未知粉末材料構造解析のためにとった詳細な手 順は次のようなものである。

Step 1）実験室系X線回折図形および放射光回折図形を 測定

Step 2）自動指数付けプログラム DICVOL ${ }^{32)}$ による格子 定数と空間群の推定

Step 3) 未知構造解析ソフトウェア FOX ${ }^{33)}$ による $\mathrm{Ge}, \mathrm{P}$, Sにより構成される多面体配列の最適化による骨 格構造を推定

Step 4) Rietveld法により,リチウムイオンを除く骨格構 造を精密化

Step 5）中性子回折データを測定

Step 6）フーリエ合成と Rietveld法により,リチウムイオ ンの位置と占有率を精密化

Step 7) 最終的な結晶構造の確定

基礎デー夕となる放射光X線回折デー夕を SPring-8 の透過型粉末回折計BL02B2 ビームラインで測定した. 試料を直径 $0.3 \mathrm{~mm}$ の石英キャピラリーに真空封入し, 大型デバイシェラーカメラ ${ }^{34), 35)}$ を用いて測定を行っ た。 測定条件は, $200 \mathrm{~K}, 1.0^{\circ}<2 \theta<70^{\circ}$ の範囲を $0.01^{\circ}$ ステップとした. 放射光 X線回折図形の初期構造解析 には，プログラムRIETAN-FP ${ }^{36)}$ を用いた，中性子回折 デー夕はJ-PARC/MLF の TOF 型高分解能中性子回折計 BL08 SuperHRPD ${ }^{37)}$ を用いて測定した. 中性子回折測定 条件は, 室温, 最高分解能バンク (背面バンク)を用い, 測定範囲を $0.5<d(\AA)<5$ とした. 結晶構造解析には,

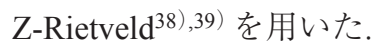

ここからは, 未知結晶構造解析を行った結果を示す. 基本となる結晶格子の情報を得るために, プログラム DICVOL06 ${ }^{32}$ を用いて指数付けを行い, 空間群と格子 定数を求めた. いくつかの候補の中から, 消滅則 $: h k 0$ : $h+k=2 n, h k l: l=2 n, 00 l: l=2 n, h 00: h=2 n$ の関 係性が得られ, この消滅則を満たす空間群として, 正方 晶の空間群 $P 4_{2} / n m c （ 137 ）$ がこの回折図形と最も一致 
(a)
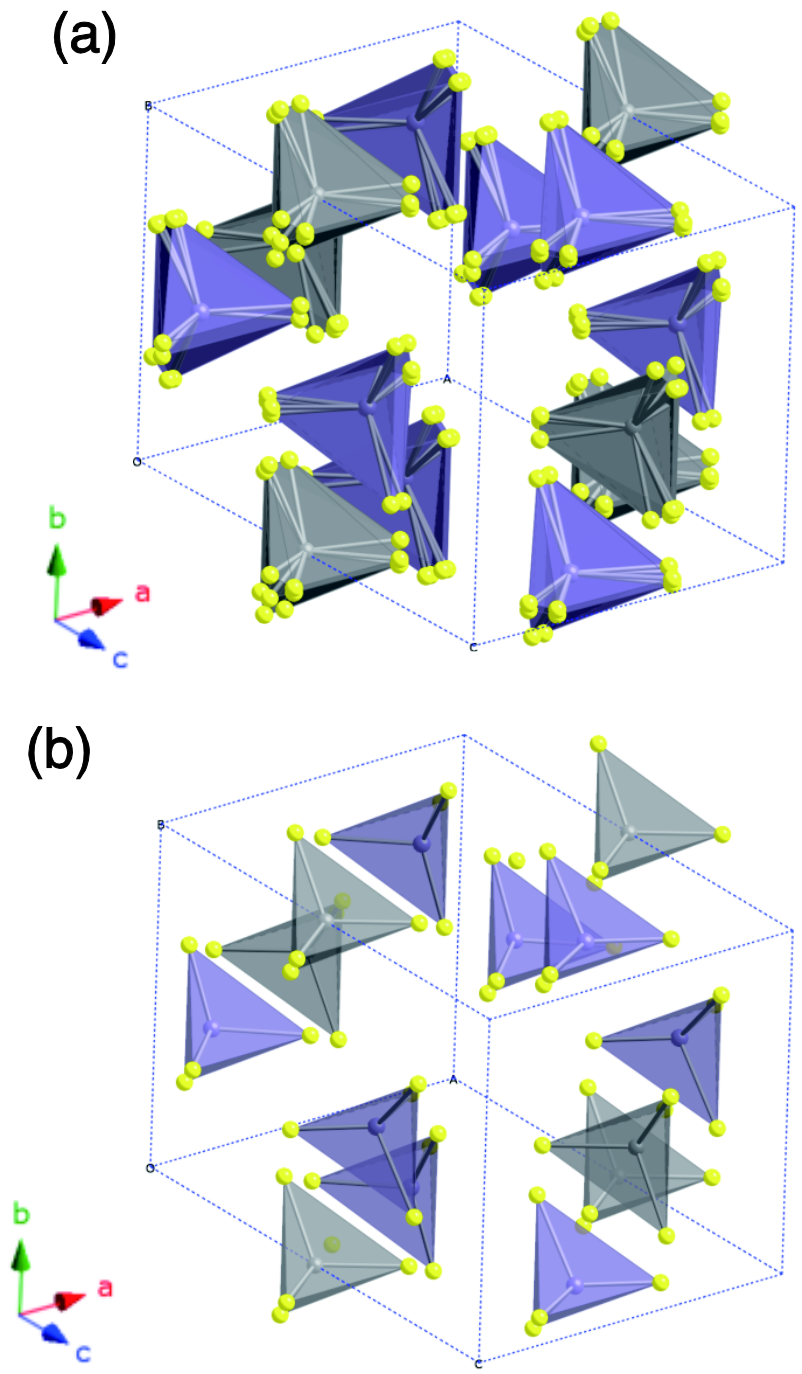

図6 FOXによるLGPS系の結晶モデル中の $\mathrm{GeS}_{4}, \mathrm{PS}_{4}$ の多面体分布シミュレーション結果 (a) と解析 モデル (b). (The simulation results (a) of $\mathrm{GeS}_{4}, \mathrm{PS}_{4}$ tetrahedra arrangement by the FOX program and the refinement model (b).)

した．正方晶を仮定した格子定数は $a=8.6975 \AA, c=$ $12.6105 \AA$ となり, 単位格子サイズを決定することがで きた．次に，この単位格子内における $\mathrm{Ge}, \mathrm{P}, \mathrm{S}$ が生成す る多面体分布を解析することとした。この解析には, プ ログラム $\mathrm{FOX}^{33)}$ を用いた. FOXは, ab initioシミュレー ションを取り达んだ構造解析ソフトウェアで, 単位格子 中で $\mathrm{GeS}_{4}, \mathrm{PS}_{4}$ などの多面体配置をシミュレートし, そ の構造因子と回折プロファイルを比較できることが最 大の特徴である。このソフトウェアを利用して, 放射光 X線回折データからリチウムイオンを除く骨格構造を導 き出すための解析を行った. FOX は, 必ずしも完全な解 だけを与えてくれるわけではない. 図6aに示すように多 面体がほぼ同位置に存在し, わずかに重なってズレた多 面体構造を配置した結晶構造モデルを解として与えるこ ともある。しかし, 丁寧にそのような構造モデルを見て

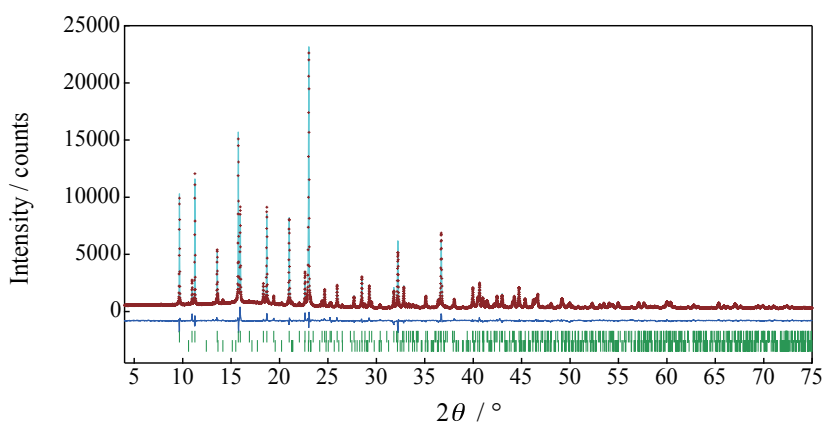

図7 放射光 X線の Rietveld 解析結果. (Synchrotron XRD Rietveld refinement pattern for LGPS.)

いくと, 最終的に Rietveld解析に用いられる結晶構造モ デルとなる $\mathrm{GeS}_{4}, \mathrm{PS}_{4}$ の分布が見えてくる. 重複した多 面体を取り除き, 構造モデルとして図6bに示すような 多面体分布を考案した。 この構造モデルが正しいかどう かを確かめるために，この構造モデルをもとに，放射光 X線回折図形を Rietveld 法により解析することにした. Rietveld解析図形を図7に示す。図7の回折図形では, 結 晶モデルを用いた計算值と観測值が大変よく一致してい ることが示されている。このことにより FOXが導き出し た $(\mathrm{Ge}, \mathrm{P}) \mathrm{S}_{4}$ 多面体が作る骨格構造が, この粉末結晶の 基本構造であると推定した。ここまでの解析により, ス テップ 4 まで解析が進み, リチウムイオンを含まない結 晶構造を明らかにすることができた。

次のステップは, Li イオンの位置と量を明確にするこ とである。そのために中性子粉末回折測定を行った。中 性子回折実験は, 大強度陽子加速器施設 (J-PARC) の物 質・生命科学実験施設 (MLF) に設置されている BL08 TOF 型超高分解能中性子粉末回折装置SuperHRPD で 行った. 回折データは, 直径 $6 \mathrm{~mm}$ のバナジウムサンプ ル管に試料を充填し, 背面バンクおよび 90 度バンクに より測定した。リチウムイオンの位置は, $\mathrm{GeS}_{4}, \mathrm{PS}_{4} に よ$ る骨格構造の隙間を考察すると推測することができた。 さらに中性子回折データのフーリエ合成図から位置を 決定し初期構造モデルとして骨格構造とした。図6bの 結晶モデルに, リチウム位置として3つの位置を追加し たモデルを仮定し, Rietveld解析により構造の精密化を 行った. その結果, 計算值と観測值のよい一致が得られ たため, 1つの構造モデルとして報告した.30)この論文が 発表された後, 短時間の間に複数の計算化学的手法に よる関連論文が発表された。そのうちの1つでAdamsら が，新たなリチウム位置を 1 つ提案した. ${ }^{40)}$ その Li位置 を取り达んで解析した結果, さらによいフィッティング を行うことができ, Li位置が4つある構造モデルが正し いものと考えている. 最終的に, LGPS系固体電解質の 構造は, リチウム位置 $(\mathrm{Li} 1: 16 h(x=0.247, y=0.267$, $z=0.198)$, Li2 : $4 d(z=0.953)$, Li3 $: 8 f(x=0.248)$, 


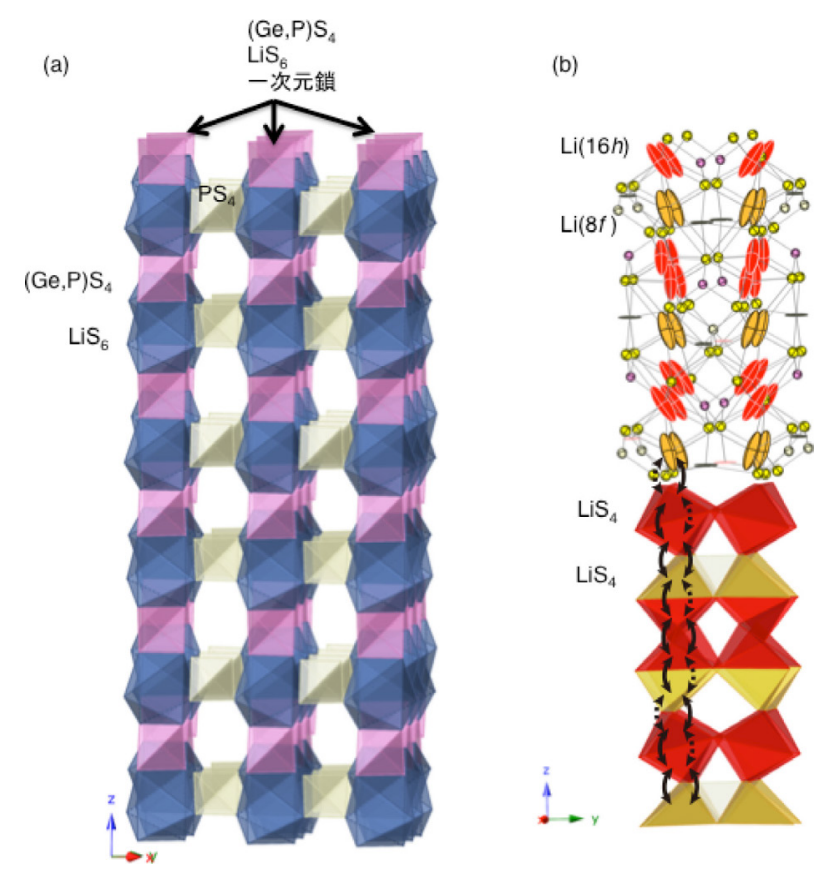

図8 LGPSの骨格構造とリチウムイオン配置.（The framework structure and lithium ions arrangements of LGPS.)

Li4 : $4 c(z=0.266))$ とした. Ge と P位置は2つの位置が あり, Ge1位置 $(\mathrm{Ge} 1(\mathrm{P} 1): 4 d(z=0.688))$ は, $\mathrm{Ge}$ と $\mathrm{P}$ が同一位置を占めるが, Ge2 位置 $(\mathrm{Ge} 2: 2 b)$ はPだけが 占めている. また硫黄は 3 つの位置 $(\mathrm{S} 1: 8 g(y=0.188$, $z=0.409), \mathrm{S} 2: 8 g(y=0.295, z=0.095), \mathrm{S} 3: 8 g(y=$ $0.696, z=0.795))$ を占める. この材料の結晶構造を図 8 に示す。骨格構造は, $\left(\mathrm{Ge}_{0.5} \mathrm{P}_{0.5}\right) \mathrm{S}_{4}$ 四面体と $\mathrm{LiS}_{6}$ 八面体 が稜を共有して形成された一次元鎖が $\mathrm{PS}_{4}$ 四面体によっ て連結された構造である. $16 h$ 位置と $8 f$ 位置を占めるリ チウムイオンが $\mathrm{LiS}_{4}$ 四面体を形成している。またそれ らのイオンの原子変位パラメータが大きく $c$ 軸方向に 広がっており, $c$ 軸方向のリチウムイオンが拡散してい ると推察される，さらにMEM解析によるリチウムイオ ンの核散乱長密度がこの Li1 と Li3 を含む $c$ 軸方向に広 がっていることから, イオン導電は $c$ 軸方向の一次元拡 散であることが裏付けられた，高温においては，Li4位 置のリチウムイオンがLi1 とLi3の導電経路とつながり, 三次元の導電へと変化することが最新の MEM解析によ り指摘されている. 41$)$

このように合成した新規物質が未知構造であったとし ても，X線と中性子線のマルチプローブ粉末回折図形か ら結晶学ソフトウェアを駆使することで構造解析するこ とができ, イオン導電機構の推定まで可能になるのは結 晶学の発展によるところが大きく, 材料研究はその恩恵 をおおいに受けることができた。

\section{6. 次世代の固体電解質探索と結晶学}

固体電解質だけでなく機能性材料全般において新規材 料を探索している現場において，さまざまな合成条件に より多くの新物質を合成されている. 合成した試料は, 回折測定, 物性測定をルーチンワークとして行い, 常に 物性と構造の関係性を確認している。このLGPS系の固 体電解質のように新物質が合成された場合, 予想もつか ない構造が現れることがある。 それも多くの場合, 得ら れる結晶は単結晶ではなく多結晶粉末であり, 結晶構造 解析は容易ではない. 材料研究者の多くは結晶学が専門 ではないため, その構造解析のハードルは壁のように高 く, 研究推進の障壁となる。しかし, 構造は物性の発現 と直結しており，その材料の機能をさらに引き出すた めの材料設計には, 構造情報が必要不可欠である。つま り, せっかくよい材料を作り出しても, その構造が解け なければ大きな発見も世界との競争の中で開花せず, 埋 もれていってしまう可能性もある. そのような状況で, 粉末回折図形を用いた構造解析の手法として, 直接法が 比較的容易にできるツールが存在しているということ は, 材料研究者にとってはきわめて重要である.たとえ 直接法により構造が完全に解けないとしても, ほかの手 法を借りながら, 最終的に構造が解けることが重要だ。 そのため材料研究者は，扔そらく結晶学を専門とする研 究者よりも, 構造解析ソフトウェアに期待するものは大 きい. 材料研究において, 粉末構造解析で主に使われる Rietveld解析ソフトゥェアとして, GSAS-II, ${ }^{42}$ FullProf, ${ }^{43)}$ RIETAN-FP, Z-Rietveldなど多くのソフトウェアが切磋 环磨しながら，解析の精度や使い勝手を向上していただ けているのは, 今後の材料研究のうえで非常に頼もしい. しかしRietveld解析は結晶モデルが必要なため, 既知構 造を解析するには強力なツールであるが，まったくの新 規物質に対して無力に近い. 今後, 多結晶粉末の未知構 造を解くために, 直接法の開発がさらに進むことを期待 したい.

高エネルギー加速器研究機構物質構造科学研究所の 構造科学グループでは, Z-Code という粉末構造解析ソ フトゥェアの総合パッケージを開発するプロジェクト を進めている. 結晶学だけでなく, 数学, 物理, 化学, 材 料の研究者が集まり, 知恵を出し合いながら, どの分野 の最先端の研究にも役立ち, どのレベルのユーザにも満 足できるよう使い勝手を向上させている。このプロジェ クトでは直接法開発も 1 つの目標である. 最近, この直 接法開発の最初の 1 歩とも言える指数付けプログラム conograph ${ }^{44), 45)}$ が富安によって開発され公開された。グ ラフ理論という手法を用いたこれまでとは違ったアプ ローチによる指数付けプログラムである. 直接法による 構造解析技術は $\mathrm{EXPO}^{46)}$ やFOXなど海外が先行してい 
るが, 国内からも是非そのような革新的なアプローチに よる研究が進むことを期待している. 結晶学は材料研究 の推進になくてはならない研究分野である. 材料研究の さらなる展開ために, 結晶学が今後も進歩することを期 待する。

\section{謝 辞}

LGPS 系は, 東京工業大学 菅野了次先生, 平山雅章先 生, 鈴木耕太先生, Kwon Ohmin氏, トヨ夕自動車 加藤 裕樹氏, 斎藤俊哉氏, 川本浩二氏, KEK 神山崇先生と の共同研究によるものである. 放射光実験は SPring-8 の透過型粉末回折計BL02B2ビームラインで実施し た(Proposal No.2010A1584). また中性子回折実験は, 大強度加速器実験施設 (J-PARC) の物質生命実験施 設（MLF）に扔いて実施した(Proposal No.2009B0039, 2010A0060)，関係各位に深く感謝いたします。

\section{文 献}

1) C. Tubandt and E. Lorenz: Z. Phys. Chem. 24, 513 (1914).

2) T. Takahashi, O. Yamamoto, S. Yamamoto, S. Yamada and S. Hayashi: J. Electrochem. Soc. 126, 1654 (1974).

3) T. Takahashi, R. Kanno, Y. Takeda and O. Yamamoto: Solid State Ionics 3-4, 283 (1981).

4) N. Weber and J. T. Kummer: Proc. $21^{\text {st }}$ Annu. Power Sources Conf. 21, 42 (1967).

5) D. S. Demott and P. Hancock: Proc. Brit. Ceram. Soc. 19, 193 (1971).

6) H. Reiss and J. O. Mccaldin: "Progress in Solid State Chemistry 7", Pergamon Press, 141 (1972).

7) A. Rabenau: Solid State Ionics 6, 277 (1982).

8) P. M. Richards: J. Solid State Chem. 33, 127 (1980)

9) G. Adachi, N. Imanaka and S. Tamura: J. Alloy. Compd. 323-324, 534 (2001).

10) T. H. Etsell and S. N. Flengask: Chem. Review 70, 339 (1970).

11) http://www.dailymail.co.uk/news/article-2263126/Dreamlinermeltdown-hi-tech-Boeing-jets-grounded-Europe-U-S-amid-fearselectric-car-batteries-trigger-fires.html

12) G. Chiodelli, A. Magistris and A. Schiraldi: Electrochimica Acta 19, 655 (1974).

13) B. B. Owens and G. H. Argue: Science 157, 308 (1967).

14) C. R. Schlaikjer and C. C. Liang: "Fast Ion Transport in Solids" (ed. W. van Gool), p.685, North-Holland, Amsterdam (1973).

15) T. Lapp, S. Skaarup and A. Hooper: Solid State Ionics 11, 97 (1983).

16) M. S. Whittingham and R. A. Huggins: National Bureau of Standard (NBS) Spec. Publ. 364, 139 (1972).

17) R. Kanno, Y. Takeda, A. Matsumoto and O. Yamamoto: J. Solid State Chem. 75, 41 (1988).

18) Y. Inaguma, L. Chen, M. Itou and T. Nakamura: Solid State Ionics 70-71, 196 (1994).

19) H. Y-P. Hong: Mater. Res. Bull. 13, 117 (1978).

20) J. Kuwano and A. R. West: Mater. Res. Bull. 15, 1661 (1980).

21) Y-W. Hu, I. D. Raistrick and R. A. Huggins: J. Electrochem. Soc. 124, 1240 (1977).
22) J. Kuwano, M. Nagamine, M. Higuchi and M. Kato: Denki Kagaku 49, 667 (1981).

23) M. Tachez, J-P. Malugani, R. Mercier and G. Robert: Solid State Ionics 14, 181 (1984).

24) B. T. Ahn and R. A. Huggins: Mater. Res. Bull. 24, 889 (1989).

25) F. W. Poulsen, N. H. Andersen, B. Kindl and J. Schoonman: Solid State Ionics 9-10, 119 (1983).

26) R. A. Huggins: Electrochem Acta 22, 773 (1977).

27) H. Obayashi, R. Nagai, A. Gotoh, S. Mochizuki and T. Kudo: Mat. Res. Bull. 16, 587 (1981).

28) M. Nishijima, T. Kagohashi, M. Imanishi, Y. Takeda, O. Yamamoto and S. Kondo: Solid State Ionics 83, 107 (1996).

29) R. Kanno and M. Murayama: J. Electrochem. Soc. 148, A742 (2001).

30) M. Murayama, R. Kanno, Y. Kawamuto and T. Kamiyama: Solid State Ionics 154-155, 789 (2002).

31) J. B. Goodenough, H. Y-P. Hong and J. A. Kafalas: Mat. Res. Bull. 11, 203 (1976).

32) A. Boultif and D. Louer: J. Appl. Cryst. 37, 724 (2004).

33) V. Favre-Nicolin and R. Cerny: J. Appl. Cryst. 35, 734 (2002).

34) E. Nishibori, M. Takata, K. Kato, M. Sakata, Y. Kubota, S. Aoyagi, Y. Kuroiwa, M. Yamakata and N. Ikeda: Nuclear Instruments and Methods in Physics Research A 467-468, 1045 (2001).

35) M. Takata, E. Nishibori, K. Kato, Y. Kubota, Y. Kuroiwa and M. Sakata: Advances in X-ray Analysis 45, 377 (2002).

36) F. Izumi and K. Momma: Proc. XX Conf. Appl. Crystallogr. Solid State Phenom. 130, 15 (2007).

37) S. Torii, M. Yonemura, T. Y. S. Panca Putra, J. Zhang, M. Ping, T. Muroya, R. Tomiyasu, T. Morishima, S. Sato, H. Sagehashi, Y. Noda and T. Kamiyama: J. Phys. Soc. Jpn. 80, SB02 (2011).

38) R. Oishi, M. Yonemura, Y. Nishimaki, S. Torii, A. Hoshikawa, T. Ishigaki, T. Morishima, K. Mori and T. Kamiyama: Nuclear Instruments and Methods A600, 94 (2009).

39) R. Oishi-Tomiyasu, M. Yonemura, T. Morishima, A. Hoshikawa, S. Torii, T. Ishigaki and T. Kamiyama: J. Appl. Cryst. 45, 299 (2012).

40) S. Adams and R. P. Rao: J. Mater. Chem. 22, 7687 (2012).

41) R. Kanno and Ohmin Kwon (private communication).

42) https://subversion.xor.aps.anl.gov/trac/pyGSAS

43) J. Rodriguez-Carvajal: Physica B. 192, 55 (1993).

44) R. Oishi, M. Yonemura, T. Ishigaki, A. Hoshikawa, K. Mori, T. Morishima, S. Torii and T. Kamiyama: Zeitschrift für Kristallographie Supplements 30, 15 (2009).

45) http://research.kek.jp/people/rtomi/ConographGUI/web_page_ JP.html

46) A. Altomare, C. Cuocci, C. Giacovazzo, A. Moliterni, R. Rizzi, N. Corriero and A. Falcicchio: J. Appl. Cryst. 46, 1231 (2013).

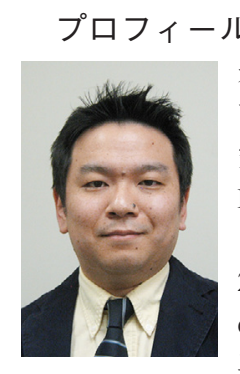

米村雅雄 Masao YONEMURA

高エネルギー加速器研究機構・物質構造科学研 究所

High Energy Accelerator Research Organization 干 319-1106 茨城県那珂郡東海村白方 203-1

203-1 Shirakata, Tokai, Ibaraki 319-1106, Japan e-mail: yone@post.kek.jp

専門分野: 固体化学, 中性子回折, 結晶構造解析 現在の研究テーマ: 機能性材料の in situ測定に よる結晶構造解析 